\title{
EXPLORING REASONS BEHIND JOINING ENGLISH LANGUAGE CENTERS (ELC): A CASE STUDY OF PASHTO SPEAKING UNDERGRADUATES IN QUETTA CITY
}

\section{Zainab Akram}

Assistant Professor, Department of Education,

Sardar Bahadur Khan Women's University, Balochistan,

Pakistan

Email: zainabmazhar1509@gmail.com

\section{Hina Arfeen}

M.Phil. Scholar, Department of Education,

Sardar Bahadur Khan Women's University, Balochistan,

Pakistan

\section{Khadija Karim}

M.Phil. Scholar, Department of Education,

Sardar Bahadur Khan Women's University, Balochistan,

Pakistan

\begin{abstract}
English language centers prove to be very helpful in being one of the major contributors of English language learning in expanding circle countries of concentric model introduced by Kachru (1989). This study undertakes the theory presented by Stephen Kreshan $(1981,1982)$ "monitor model" which is basically amalgamation of five hypotheses. This very endeavor was done through quantitative mode of inquiry utilizing survey questionnaire as an instrument for data collection. Total population was Pashto speaker students of Quetta city and sample size comprised of 100 undergraduates, particularly, the Pashto speakers, from Quetta city. Collected data was analyzed through SPSS software. The Findings show various reasons behind students joining English language centers. Some of them include good environment of ELC, along with several academic, personal, and instrumental reasons. It is recommended that in future the research could be expanded to multiple case studies comprising Pashto speakers and multilingual, longitudinal research,
\end{abstract}


and comparative study between teaching English at school and language centers.

\section{KEYWORDS}

English language, English language learning, English language centers (ELC), Pashto speaking students

\section{INTRODUCTION}

\section{Pashto Language Speakers}

Language is a priceless gift of God to human being. Without it human being would have remained only a dumb animal. (Jamil, Majoka \& Khan, 2014). Pakistan is a country where Pashto is being spoken round about 35 to 40 million people as their native/first language. It makes $15.42 \%$ of Pakistan's whole population that is 208 million people. In Khyber Pakhtunkhwa and Northern Balochistan, this language cherishes the position of being main language in Pashtun-majority regions. Not only in these two provinces but this language is being spoken in parts of Mianwali and Attock districts of Panjab and Islamabad, in Sindh communities speak modern Pashto, and in many other cities throughout the country where Pashtuns reside Pashto can be found easily. Urdu and English share the status of being official languages in Pakistan. Rehman (1995) states that Pakistan is a multilingual country where Pashto is not the language of entire state, thereby, plays a very limited role despite the fact that it is native language of 70 to $80 \%$ people residing in Khyber Pakhtunkhwa and northern Balochistan. Pashto does not have any official status at federal level but on provincial level these two provinces make it their regional language. The primary medium of education in government schools in Pakistan is Urdu, but from 2014 onwards, the Government of Khyber Pakhtunkhwa has placed more emphasis on English as the medium of instruction. English-medium private schools in Pashto-speaking areas, however, generally do not use Pashto. This language along with many other native languages of Pakistan has faced systematic degradation and decline by the imposition of Urdu as the primary medium of education in public schools. Pashto speakers complains about their native language being neglected at official level due to which there is growing resentment found amongst Pashtuns.

\section{English Language}

Due to the fact that English is international language and the language of modern science, a person's knowledge hinges on the size of English vocabulary 
he / she owns. The success of an individual in second language is dominated by his / her vocabulary (Jamil et al., 2014). Since English language became one of the official languages and the medium of instruction in some countries, from the perspective of the learning process, the factors influencing language learning can be outlined as learning styles and strategies, motivation, and classroom interaction. English language is the language that has been the only compulsory foreign language in some of the non-native English countries in schools since around 1970. Out of all the foreign languages, English has earned the reputation of second language across the globe.

According to Walqui (2000) some researchers studied the problems on the attitude of the pupils toward second language. Many pupils in non-native English speaking country showed different responses and find difficulties in learning English language. Speakers (n.d) asserts that English language is still one of the main problems of the student today in non-native English speaking countries. Moreover, students do not want to come into their English classes as they are afraid to communicate using English language, and they are afraid to commit mistakes while using English. That is why the chances of their improving efficiency in English language decreases, and in some cases pupils do not want to study English subject and seem to show positive and negative attitudes towards it (Walqui, 2000).

\section{English in the World}

Mckay (2002) states that the number of people using English is developing with every passing day. So, this growth is filled with the advantages that English language provides, more opportunities and assistance to those who are familiar with it and know how to utilize appropriately. Crystal (2003) states that in terms of extending the utilization of English language around the globe, it has really achieved a high rank and status in more than seventy-five countries, though the status of English language varies from one state to the other. Kachru (1989) explained the status of English language in three levels in the figure of his concentric circle model., which are: 1. The inner Circle, where English language is utilized as first language, for instance, in America, Australia, UK and Canada; 2. The outer circle, the states where English language is in use at second language in the countries with diversity of language, for example, Pakistan, India, Singapore; 3. The Expanding Circle, these are the areas where English is viewed as foreign language such as China, Korea, and Japan (p. 87). Mckay (2002) states the fact that spread of English throughout the world has 
become utmost important and mandatory for any country which desires to be global community's respective part. This can be researched and deduced from the growing number of those who want to acquire or learn English language to get the benefits in different fields. The demand for English Language Teachers (ELTs) has surged as the number of English speakers have grown. Pennycook (1994) states that spread of English language and growth of the numbers of ELTs have mutual relation. In more than 100 countries, English has become most widely taught and learnt language throughout the globe (Crystal, 2003).

\section{English in Pakistan}

Pakistan is a multi-lingual country where English is taught as a second language (ESL) and English is taught as foreign language (EFL) (Manzoor, Ahmed, \& Gill, 2014). It enjoys a status of second language as it is used extensively for many purposes in society (Farooq, uzair-ul-hassan, \& Wahid, 2012). English is compulsory at primary level but it is observed that the students at early age are not interested in learning English and do not feel happy to attend English language class (Manzoor et al., 2014). As far Pakistan is concerned, the significance of English within Pakistani society is rooted since its independence (Mahboob, 2009). As Mehboob (2009) states “...when Pakistan gained independence from the British, the English language had become so entrenched in the sociopolitical fabric of the region that it was reserved as an official language..." (p. 178) In the realm of education, Nunan (1992) asserts that Anecdotal evidence suggests that English is introduced as a compulsory subject owing to the increasing world demand for English but frequently without adequate planning, with no proper teachers training or the development of curricula and materials at younger ages by the governments throughout the world. Pakistan is one of those countries where English is valued and used in almost every official aspect including education as second language (Saeed, Iqbal \& Azam n.d). Though, it is a second language it makes the scenario quite surprising by not having native speakers still marginalizing all other local languages within Pakistani society whereas other local languages are socially neglected and considered as sidelined languages (Manan, Dumanig \& David, 2014).

\section{The English language canters}

ELC are particularly, established with the purpose to serve and help students learn and achieve degrees of capabilities and potential towards learning and speaking English language. Leather \& James (1996) suggest that the 
accomplishment towards learning and teaching English rests on students' capability and exposure. The more they get opportunity to learn and practice a language, the more productive output is seen. The Pashto speakers have a peculiar accent towards speaking and pronunciation English vowels and consonants. Various Languages have different accents, depending on geographical locations, social classes, ages and different educational backdrops (Roach, 2000). Multiple factors are brought forward in pronunciation errors, understanding, and confidence, and fluency for Pashto speakers towards English language: Influence of the mother tongue, especially in pronunciation, syntax, and idiomatic usage. Dearth of opportunity and chances to use English in the daily lives. Unchallenging English lessons, usually based on route and GTM system of learning. The passivity of the learners. The shyness to speak English with classmates. Lack of holding responsibility for their own learning and productivity (as cited in Tegey \& Robson, 1996). The ELC, are especially set to meet the shortcomings among the students towards learning and speaking correct English.

Learning a language is closely related to the attitudes towards the languages (Starks \& Paltridge, 1996). Preparing students whose native language is not English for a world where English is considered a prime and primary language is very challenging indeed. These students need strong language skills that are in accordance with industry needs (Mahdi, 2015). By studying the ways in which groups of people, families, schools, and social communities connect and contrast in their education hones/practices we can get noteworthy bits of knowledge into how individuals learn, instruct, arrange, negotiate and get to proficiency both inside and outside school settings (Norton, 2010).

The problem the researcher intends to investigate in this study is to explore the basic reasons behind Pashto speaking students' need of joining English Language Centers even after studying English as Second language for more or less twelve years through the perceptions of students. The input of the research can help out evaluating the language courses' appropriateness and viability to tackle Pashto speaking undergraduates' needs and getting them ready for competitive job market. Moreover, it can help with evaluating the English language courses' viability and appropriateness to provide food for the present needs of the students and readiness for the employment advertise (Singh, 2014). 


\section{LITERATURE REVIEW}

In Pakistan, of course, English has become a typical mean of correspondence. It is the most widely used language - however Urdu and other provincial and numerous languages, like Pashto are being utilized for different purposes, English assumes part of a worldwide phenomenon the lingua Franca, and in the realm of science, innovation and in different parts of current advance it's a simple medium of correspondence (Warsi, 2004).

\section{English on Global level}

Despite the fact that English is totally foreign language for huge number of people throughout the globe, no one can deny the utter significance of it in economic and educational fields internationally. People all around the world are connected through a substantial medium language. People are hampered academically who are not quite good at English language either spoken or written. Keeping in view this fact, English has been compulsory subject in curricula all over the globe (Mahdi, 2015). Over the century there has been great rivalry with other languages worldwide, for instance, Spanish, French, Russian and Chinese, in $19^{\text {th }}$ Century. Britain and America commanded world with their economies that promoted and brought fame to English language as language of most influence and importance (Sekhar, 2012). As per Crystal (1997) more or less $85 \%$ of world's global associations and organizations have English as official language in all transitional correspondence. 85\% of world's essential film making/preparations as well as other markets have great utilization of English language, other than that, around $90 \%$ of esteemed and scholastic articles are composed in English language. By and large, the expanded development in the utilization of English dialect can be credited to instructive, practical or social globalization (Crystal, 1997). Sabri and Qin (2014) revealed that more than sixty thousand graduate students living in Malaysia are unable to enter their professions of choice as they "lack English language competency" and have "poor oral communication skills". They thus remain unemployed. Other studies conducted on Malaysia graduates conclude, "Inevitably, most language teachers and instructors agree that many students in Malaysia face problems communicating in English, as it is not their native language.

English is the official language in Pakistan so it has gained important status and its medium of pedagogy at higher education and along with it, for competitive exams it's mandatory to have full command over English language (Mahboob, 
2009). Despite all the fact, students are rather inefficient in English language, students from both primary and secondary level schools. (Jamil et al., 2014). For English has gained its importance and significance throughout the world, it's necessary from child's early education to his later professional life and all that depends on unprofessional teachers (Coleman, 2010). Pakistan by all means is multilingual, multicultural and multiethnic nation. In the event that we discuss government constitution of 1973, at that point we truly realize that it made Urdu as the national and English as the official dialect (Rehman, 1996). There are 77 different languages in Pakistan and in which English and Urdu stand first because of the areas of significance and utmost importance (like organization, media, instruction, CSS, legal and so on) while different indigenous remain at base (Rahman, 1996). It is trusted that for the most part standard and nature of training of English medium schools are just related and limited to exclusive class (Mustafa 2011; Rahman 2004, 2007). Both Power and status are those characteristics which assist any language speaker with getting much regard, esteem or respect and just an effective empowers a speaker to get higher status in contrast with others in the society. That effective tongue has renowned status in the public eye for being acclaimed or universal as English or in Pakistan it is in effect gladly utilized by the young or taught individuals keeping in mind the end goal to get great status, great job, great business or great training also. It clears the view that due to English's fame in Pakistan, individuals make their wedding or going by cards imprinted in English language. English is utilized for the promotion of one's business, even their shop names or their flaxes are in English since individuals thought of it as a cutting edge or socialized language in Pakistan. English as blended abbreviated dialect has turned into a dialect of high society, instructed individuals or adolescents in Pakistan (Sadiq, 2015). English is considered as symbol to modernity. It is generally assumed about the social behavior or the mind set of Pakistanis that more English is being used the more one is considered educated and modern. English language is an essential part of daily conversation of Pakistanis either consciously or unconsciously. There are certain phonetic, pragmatic and syntactic changes that occur whenever any language is utilizes in different contexts or socio-cultural conditions. Like every other non-native speakers who put their cent in English, Pakistani English speakers also developed short forms as well as colloquial expressions as per their needs (Sadiq, 2015). Keeping in view the importance of ESL, government has introduced many policies to learn English as compulsory subject at all levels. But no reasonable improvement has been observed in this regard (Tariq 
et al., 2013). Moreover, a study conducted by Maimoona et al., (2013, cited in Manzoor et al., 2015) explains that students are less motivated in learning English if the environment is not good around them, whereas positive reinforcement can play a vital role in learning.

\section{Role of ELC}

In view of the clarification of the language necessity, it can, in this manner, be recognized that English language undoubtedly is an essential that the students are presented to in their investigation at tertiary level (Singh, 2014). Yet at the same time they can't ace the language in their school classes. . Taking in the language through different exercises joined with the perusing, composing, talking and listening abilities will enhance their capability and additionally set them up for work and that is conceivable just in classes which are particularly intended for showing English language. It tends to be noticed that the understudies are urged to take the dialect/language courses for their own academic or social improvement and for occupation purposes. Aside from that, the understudies have additionally shown that there is a requirement for variety in exercises used to show the dialect/language. It can't be denied that imperatives, for example, inadequate time, the need to finish the syllabus and coursework appraisals now and again take away the delight in taking in the dialect (Singh, 2014). While dialect fixates concentrate just on learning or it very well may be said that their essential target is showing English, tests, appraisals and so forth comes later. However, In English Language Teaching (ELT), particularly, when English is associated with Class Room Teaching (CRT), it assumes an exceptionally critical job in grabbing understudy's concentration. To obtain great relational abilities or to exceed expectations in relational abilities, one needs to secure aptitude in all the four aptitudes. They are Listening, Verbal Communication, Interpretation and Inscription/writing Skills. Before an understudy gains with every one of these abilities, he/she needs to create enthusiasm towards the subject or dialect (Mahdi, 2015). Dialect focuses assume a critical job in such manner too they build up the enthusiasm of students. Teaching of English as language is quite different from that of teaching English as subject. (Breiseth, Robertson, \& Lafond, (2011 cited in Mahdi, 2015) asserts that various Techniques and Strategies for EFL Class EFL teachers should use to build the confidence of their EFL students so that they can become more competent to be engaged in oral communication Apart from oral communication skills, there are various other tips, which can be very effective for EFL learners, as well as for teachers, to make a particular lesson 
understandable, such techniques are difficult to adopt due to lack of time and insufficient curricula at schools thereby students go for language centers as they know teaching at centers are way different then schools.

From teaching English as subject is quite different the teaching of English as Language. (Breiseth, Robertson, and Lafond, (2011 referred to in Mahdi, 2015) affirms that different Techniques and Strategies for EFL Class EFL educators should use to assemble the certainty of their EFL understudies with the goal that they can turn out to be more able to be occupied with oral correspondence Apart from oral relational abilities, there are different tips, which can be exceptionally compelling for EFL students, and additionally for instructors, to make a specific exercise justifiable, such systems are hard to receive because of absence of time and inadequate educational module at schools in this manner understudies go for dialect focuses as they probably am aware educating at focuses are way extraordinary at that point schools. Apart from that, another system which dialect focuses utilize while instructing is use of realia. Countless educators tend to utilize genuine questions in the classroom, which remarkably affects the comprehension of a specific bit of dialect learning or a marvel. As it were, realia include genuine things or articles that are utilized in the EFL classroom to embody and to educate vocabulary. Realia are likewise used to fill in as help to encourage dialect generation and procurement (Mahdi, 2015).

\section{Theoretical framework}

This research study utilizes the theoretical framework of Krashen $(1981,1982)$ which is actually named as "Monitor Model" which is commixture of five speculations or hypotheses produced for to give ground to second language acquisition. Krashen's hypothesis/theory of second language acquisition process was sophisticated over some undefined time frame and is exhibited, among different works, in Krashen (1981, 1982, 1985, 1989, 2003) and Krashen and Terrell (1983). These hypotheses are as per the following.

\section{OBJECTIVE}

1. To explore the reasons by the undergraduates, particularly, Pashto speakers, for joining English language centers for learning English language.

\section{RESEARCH QUESTION}

1. What are the reasons of Pashto speaking undergraduates towards joining ELC for learning English language? 


\section{RESEARCH METHODOLOGY}

The present study would yield quantitative research methodology. According to Murtonen (2005) Quantitative research includes the utilization and analyses most specifically of numerical data along with statistical techniques throughout the respective process. The study manifests an exploratory investigation as a quantitative research kind. Such sort of research is embraced generally to comprehend and to get knowledge and deep insight of the specific circumstance or issue where little measure of data exists. In the research design the researcher executed volunteers sampling for this examination/study. The Purposive sampling is one of the sorts of non-random inspecting which incorporate those subjects who are promptly available and would consent to partake in research study or the general population who participates willfully in the examination. Researcher planned to incorporate (100) college understudies from various academies and centers of Quetta city whose native language is Pashto for filling the survey questionnaire on the whole. These (100) undergraduate students would be chosen through purposive sampling system paying little mind to their level in focus to tell about their reasons and language focus input in these English Language Centers and academies. The study of Singh (2014) brings us to the notion that how essential it is to investigate and look at the impression of the undergraduate students' "self-evaluation" as they are the best witnesses of the required information and data. Due to the scarcity of time and the variables, for example, unwavering quality and legitimacy in terms of reliability and validity the analyst couldn't develop study questionnaire that is why adopted the available the survey created by Ghenghesh \& Nakhla (2011) to be given to the students who have joined and are still learning in English Language academies to answers to the very offered question. Likert strategy that utilized a five-point scale was adopted, where members reacted to different provided statements utilizing 'strongly agree', 'agree', 'neutral', 'disagree and 'strongly disagree'. The quantitative information gathered from understudies through poll/questionnaire is intended to get it through significant analysis by SPSS, while factual estimations and measurements would be accounted for according to the findings of information. First and second questionnaire data is entered into SPSS which truly is a statistical package for researchers. The outcomes are regularly handled by methods for distinct measurable examination to give frequencies, means, rates and ranges (Dörnyei, 2007). Questionnaire information is most usable on the off chance that it is put away in a PC files for coding for investigation and analysis. 
Pakistan Journal of Educational Research. Vol 1, Issue 2 (2018)

Exploring reasons...

\section{STATICALLY ANALYSED DATA}

\section{Table 1}

To improve my English

\begin{tabular}{llllll}
\hline & & Frequency & Percent & $\begin{array}{l}\text { Valid } \\
\text { Percent }\end{array}$ & $\begin{array}{l}\text { Cumulative } \\
\text { Percent }\end{array}$ \\
\hline \multirow{3}{*}{ Valid } & Strongly Agree & 96 & 96.0 & 96.0 & 96.0 \\
& Agree & 4 & 4.0 & 4.0 & 100.0 \\
& Total & 100 & 100.0 & 100.0 & \\
\hline
\end{tabular}

Table 2

Because of my Urdu medium academic background

\begin{tabular}{|c|c|c|c|c|c|}
\hline & & Frequency & Percent & $\begin{array}{l}\text { Valid } \\
\text { Percent }\end{array}$ & $\begin{array}{l}\text { Cumulative } \\
\text { Percent }\end{array}$ \\
\hline \multirow{6}{*}{ Valid } & Strongly Agree & 17 & 17.0 & 17.0 & 17.0 \\
\hline & Agree & 27 & 27.0 & 27.0 & 44.0 \\
\hline & Neutral & 11 & 11.0 & 11.0 & 55.0 \\
\hline & Disagree & 11 & 11.0 & 11.0 & 66.0 \\
\hline & $\begin{array}{l}\text { Strongly } \\
\text { Disagree }\end{array}$ & 34 & 34.0 & 34.0 & \multirow[t]{2}{*}{100.0} \\
\hline & Total & 100 & 100.0 & 100.0 & \\
\hline
\end{tabular}

Table 3

To progress to the English subject

\begin{tabular}{llcccc}
\hline & Frequency & Percent & $\begin{array}{l}\text { Valid } \\
\text { Percent }\end{array}$ & $\begin{array}{l}\text { Cumulative } \\
\text { Percent }\end{array}$ \\
\hline \multirow{5}{*}{ Strongly Agree } & 23 & 23.0 & 23.0 & 23.0 \\
& & & & \\
Valid & & & & & \\
& Agree & 3 & 33.0 & 73.0 & 96.0 \\
Neutral & 1 & 1.0 & 3.0 & 99.0 \\
Disagree & 100 & 100.0 & 100.0 & 100.0 \\
Total & & & & \\
\hline
\end{tabular}

Table 4

English is important and useful 
Pakistan Journal of Educational Research, Vol 1, Issue 2 (2018) Exploring reasons...

\begin{tabular}{llcccc}
\hline & & Frequency & Percent & $\begin{array}{c}\text { Valid } \\
\text { Percent }\end{array}$ & $\begin{array}{c}\text { Cumulative } \\
\text { Percent }\end{array}$ \\
\hline \multirow{4}{*}{ Valid } & Strongly Agree & 46 & 46.0 & 46.0 & 46.0 \\
& & & & & \\
& $\begin{array}{l}\text { Agree } \\
\text { Total }\end{array}$ & 54 & 54.0 & 54.0 & 100.0 \\
\hline
\end{tabular}

Table 5

I enjoy the subject

\begin{tabular}{|c|c|c|c|c|c|}
\hline & & Frequency & Percent & $\begin{array}{l}\text { Valid } \\
\text { Percent }\end{array}$ & $\begin{array}{l}\text { Cumulative } \\
\text { Percent }\end{array}$ \\
\hline \multirow{5}{*}{ Valid } & Strongly Agree & 36 & 36.0 & 36.0 & 36.0 \\
\hline & Agree & 42 & 42.0 & 42.0 & 78.0 \\
\hline & Neutral & 10 & 10.0 & 10.0 & 88.0 \\
\hline & Disagree & 12 & 12.0 & 12.0 & 100.0 \\
\hline & Total & 100 & 100.0 & 100.0 & \\
\hline
\end{tabular}

Table 6

To gain marks

\begin{tabular}{|c|c|c|c|c|c|}
\hline & & Frequency & Percent & $\begin{array}{l}\text { Valid } \\
\text { Percent }\end{array}$ & $\begin{array}{l}\text { Cumulative } \\
\text { Percent }\end{array}$ \\
\hline \multirow{6}{*}{ Valid } & Strongly Agree & 17 & 17.0 & 17.0 & 17.0 \\
\hline & Agree & 57 & 57.0 & 57.0 & 74.0 \\
\hline & Neutral & 23 & 23.0 & 23.0 & 97.0 \\
\hline & Disagree & 2 & 2.0 & 2.0 & 99.0 \\
\hline & Strongly Disagree & 1 & 1.0 & 1.0 & 100.0 \\
\hline & Total & 100 & 100.0 & 100.0 & \\
\hline
\end{tabular}

Table 7

The class and environment are interesting

\begin{tabular}{lllll}
\hline & Frequency & Percent & $\begin{array}{l}\text { Valid } \\
\text { Percent }\end{array}$ & $\begin{array}{l}\text { Cumulative } \\
\text { Percent }\end{array}$ \\
\hline Valid Strongly Agree & 46 & 46.0 & 46.0 & 46.0 \\
\hline \hline
\end{tabular}


Pakistan Journal of Educational Research, Vol 1, Issue 2 (2018) Exploring reasons...

\begin{tabular}{lllll} 
Agree & 36 & 36.0 & 36.0 & 82.0 \\
Neutral & 15 & 15.0 & 15.0 & 97.0 \\
Disagree & 2 & 2.0 & 2.0 & 99.0 \\
Strongly Disagree & 1 & 1.0 & 1.0 & 100.0 \\
Total & 100 & 100.0 & 100.0 & \\
\hline
\end{tabular}

Table 8

Can understand the lesson well

\begin{tabular}{|c|c|c|c|c|c|}
\hline & & Frequency & Percent & $\begin{array}{l}\text { Valid } \\
\text { Percent }\end{array}$ & $\begin{array}{l}\text { Cumulative } \\
\text { Percent }\end{array}$ \\
\hline \multirow{5}{*}{ Valid } & $\begin{array}{l}\text { Strongly } \\
\text { Agree }\end{array}$ & 26 & 26.0 & 26.0 & 26.0 \\
\hline & Agree & 48 & 48.0 & 48.0 & 74.0 \\
\hline & Neutral & 14 & 14.0 & 14.0 & 88.0 \\
\hline & Disagree & 12 & 12.0 & 12.0 & 100.0 \\
\hline & Total & 100 & 100.0 & 100.0 & \\
\hline
\end{tabular}

Table 9

I have friends in the class

\begin{tabular}{|c|c|c|c|c|c|}
\hline & & Frequency & Percent & $\begin{array}{l}\text { Valid } \\
\text { Percent }\end{array}$ & $\begin{array}{l}\text { Cumulative } \\
\text { Percent }\end{array}$ \\
\hline \multirow{6}{*}{ Valid } & Strongly Agree & 28 & 28.0 & 28.0 & 28.0 \\
\hline & Agree & 25 & 25.0 & 25.0 & 53.0 \\
\hline & Neutral & 11 & 11.0 & 11.0 & 64.0 \\
\hline & Disagree & 25 & 25.0 & 25.0 & 89.0 \\
\hline & Strongly Disagree & 11 & 11.0 & 11.0 & 100.0 \\
\hline & Total & 100 & 100.0 & 100.0 & \\
\hline
\end{tabular}

Table 10

The number of students in the class is small

\begin{tabular}{|c|c|c|c|c|c|}
\hline & & Frequency & Percent & $\begin{array}{c}\text { Valid } \\
\text { Percent }\end{array}$ & $\begin{array}{l}\text { Cumulative } \\
\text { Percent }\end{array}$ \\
\hline \multirow{4}{*}{ Valid } & Strongly Agree & 2 & 2.0 & 2.0 & 2.0 \\
\hline & Agree & 28 & 28.0 & 28.0 & 30.0 \\
\hline & Neutral & 46 & 46.0 & 46.0 & 76.0 \\
\hline & Disagree & 10 & 10.0 & 10.0 & 86.0 \\
\hline
\end{tabular}




$\begin{array}{lcccc}\text { Strongly } & 14 & 14.0 & 14.0 & 100.0 \\ \text { Disagree } & 100 & 100.0 & 100.0 & \\ \text { Total } & \end{array}$

Table 11

Interesting class, material, activities

\begin{tabular}{lllll}
\hline & Frequency & Percent & $\begin{array}{l}\text { Valid } \\
\text { Percent }\end{array}$ & $\begin{array}{l}\text { Cumulative } \\
\text { Percent }\end{array}$ \\
\hline Strongly Agree & 36 & 36.0 & 36.0 & 36.0 \\
Valid Agree & 46 & 46.0 & 46.0 & 82.0 \\
Neutral & 18 & 18.0 & 18.0 & 100.0 \\
Total & 100 & 100.0 & 100.0 & \\
\hline
\end{tabular}

\section{FINDINGS AND DISCUSSION}

For good or bad, English has remained with us even in post-independence period. It has been accorded the status of an official language of the country which provides people, students with different reasons to learn English if they want to progress. The result of the study shows that there are different general reasons such as academic, personal, socio cultural and other factors, explored from Pashto speakers, behind joining English language centers even after studying English for more than twelve years still students at graduate level find necessary to go for specific English language classes. The highest ranked response made by students of very first statement of questionnaire (to improve my English) clarifies the notion where $96 \%$ of the students strongly agreed with the statement. It shows that even after being in touch with English for many years still students needed to improve their English. Shah (2008) asserts that in urban areas of the country English medium schools can be found in every nook and corner in a state where students are coming to classroom from different linguistics backgrounds, speaking number of regional languages. It is difficult to meet the challenges of providing quality English language teaching where as there are fewer recourse to be utilized for quality education. In reality, the English medium schools are just selling socio economic dreams not provision of quality education is being found. According to Krashaen, (1981, 1982) there is difference between acquisition and learning a language. Acquisition needs natural interaction and environment where as for learning we need to provide the environment, thereof it is important to provide such 
environment which is helpful for students learning English as second language. One of the lowest ranked statement (because of my Urdu medium academic background) where $34 \%$ of the student strongly disagreed with the statement shows that it has nothing to do with their school background be it Urdu medium or English medium but they wanted to join these English language classes offered by different language centers. As learning English was depending upon quality of education being provided to them not school medium. Researcher believes that ten years of education regarding English at school where they are being provided 30 to 45 minutes each day is not enough to meet the students' upcoming needs of English. Students have to go for these classes for improvement and progressing in English language and English subject respectively, after realizing the usefulness of English. One major reason which researcher believes could be traced among Pashto speakers behind joining language centers is that, the students of Quetta city are not satisfied with their learning at school that is what leads them to difficulty in understanding in courses at college level. The notion can be supported with the response made by students of the different statements given in academic factors of questionnaire. The natural order hypothesis by kreshan $(1981,1982)$ suggests that there are some structures that are learnt earlier and some are learned later naturally regardless of age factor, this can be a reason that students were not able to learn some structures at schools at early age but at centers on later stage. English has been given the value of not only a language of elite class but a language which helps people in general and students particularly to read modern books related to different fields of life such as medical, engineering, agriculture and literature (Rehman, 2006; Shamim, 2008). It helps to understand the maximum use of latest technology. That is the reason students want to have grasp over the language before they could enter into graduate level courses and they face difficulty in doing so during their school period such as lack of interest, no proper teaching aids, old text books which do not meet modern requirements, teacher centered classroom, lack of time and in most of the cases where strength of students is very high no time at all is being provided to them during English classes, and biggest reason is that in most of the schools even teachers are not fully aware of the methodology to teach English as a second language. In the context of Pakistan, it is generally assumed that anyone who can speak good and fluent English would know how to teach it (Shamim, 2008).

However, the reality is quite contrary, in fact researchers have observed that in 
many cases teachers themselves face difficulty in speaking English but are given responsibility to teach it, ultimately students face difficulty in learning English at schools this impression can be supported by the result of a statement where $51 \%$ of the respondents strongly agreed and $30 \%$ agreed with the point that studying in English language centers helps them in their academic study of other courses. As per adopted theory human beings have monitor system while using their language which means their learning of rules and regulations related to grammar and structure of any language continuously interfere in the way of their speaking. As this system have check and balance, edit and correct language before being uttered it does not let the user to speak fluently even though they have been learning it for many years. Its example is that though at school's grammar has been focused more than anything, yet $56 \%$ of the students agreed with the point that grammatical errors are serious problem for them that's why they take classes at centers.

Good environment and positive reinforcement are one of the major factors that fosters learning in anything so is for language. English language learning is only possible when the provided environment is suitable and helpful. One of the hypotheses presented by Stephen kreshan $(1981,1982)$ embodies the view that there are some variables which can affect or facilitate both learning of a language. These variables can be motivation, confidence and anxiety etc. Positive reinforcement and motivation can help while anxiety and low selfesteem can affect language learning. Students generally are not interested in learning English at primary level the reason could be that they don't find appropriate environment for it. They find it boring due to lack of motivation. However after realizing the importance of English they go for such places where teachings have positive impact and attitude for their learning. English language centers try their best to provide good, creative and appealing environment that can attract learners and increase their want to take classes. The methodology and material used in language centers are different from that of schools. In language classes provided by centers various activities are incorporated and helpful and positive role played by the instructor increase interest in learners and motivates their learning. The thought can be held through the response made by students of different statements from questionnaire's one area instructional factor domain where students responded to almost all statements in quite positive way and majority of the responses were about strongly agree and agree on the response scale. The statement, 'my instructor encourages me to participate' got $52 \%$ strongly agree and $46 \%$ agree 
response, while the statement, 'pair and group work in encouraged in ELC' got $49 \%$ agree and $46 \%$ strongly agree response.

According to the results of a study based on motivational learning of English for Pakistani learners conducted by Rehman et al., (2014) manifest that Pakistani learners' biggest motivation towards learning English is instrumental. According to the present study too instrumental factor is one of the main reasons that emerged from the result of the study. Students know that if they want to have good jobs in future, they need to be efficient and fluent in English language in present era. They believe their future entirely depends upon the level of their English language along with other skills. This is to some extent true as well. As Yahya (2012) states that in present era companies welcome only those candidates for being their employees who have fluency in English and have relevant qualification and skill set. However, candidates with relevant qualification but poor knowledge and fluency in English are being rejected. The concept can be highlighted by the result of a statement where $47 \%$ of the respondents strongly agreed and $28 \%$ agreed with the point that they will need English in their future. Whereas 56\% of the respondents agreed and $46 \%$ strongly agreed with the point that English is important and useful. It can be concluded that students want to study English for instrumental reasons as English is seen as synonymous with progress and prosperity.

Another motive according to the researcher that can be found by the results is personal interest. Personal interest is also one of the reasons by Pashto speaking students behind their going to language classes. It was their personal interest which grabbed their attention to learn English and consequently they went to English language centers. One of the highest ranked statement from the area of socio cultural factor, where $59 \%$ of the students agreed and 26\% strongly agreed with point that their family encourages them to learn English shows that going to language centers is due to their family's positive attitude towards English. They were aware of the fact that the supremacy of English has maintained and existed in the society through English education for the elite, another highest ranked statement supports the notion where $51 \%$ respondents agreed and 35\% strongly agreed that they feel proud among fellows while they speak English. Researcher found that some of the respondents wanted to learn English just because of the fascinating image of the language they had in their minds or they simply liked the language due to its increased demand or it is "in" these days, so they wanted to learn it to have a distinct position among 
their fellows or in the society. So, they were interested in learning English language.

\section{CONCLUSION}

Due to the different structure and norms of native language acquiring any second language is not easy task for new learners and they commit mistakes even after several years of learning. This is the case with learners of Quetta city students too. Being students of graduate level, they lack perfection in the linguistics skills of English. While English is concern, the learners of second language come across many problems in acquisition of English language. Number of mistakes can be found especially in the writing skill of students such as grammatical errors, difficulty in correct use of verb, surface problem, issues related to content, incorporating syntactical structure within a sentence, semantic interpretation, the process of writing itself as they lack vocabulary, problematic use of conditional sentence and punctuation marks. Major reasons due to which these problems arise are less skilled and less qualified teachers along with poor education and assessment system, school environment with high strength classes is another factor that hinders language acquisition. One of the reasons that affect language acquisition or learning at early stage is attitude towards language and use of local languages such as Urdu and mother tongue in the classroom. As Nawaz et al., (2015) states that the Procedure of thinking in Urdu and then translating it into English is enrooted like a germ in our students.

The study found that learners were not comfortable with old methodologies that were being practiced in their schools or early education specifically for teaching English. They needed something new and creative. In order to teach students appropriately teachers must go towards creative and innovative methods in teaching composition, vocabulary and other language skills. Thereof it's better to adopt eclectic approach instead of relying upon old methodology in their teaching and training students for proper word, grammar, structure selection. Students should be told how to tackle the interference of first language and the mistakes that occurs due to first language especially in terms of its syntax while using English language. Eclectic approach must be practiced and appreciated to inculcate knowledge of both genre and process of writing (Yahya, 2012).

It is evident that $80 \%$ of the teachers do not have enough qualification to teach English as second language. And merely rest of the $20 \%$ can be said to be 
qualified to some extent as they are equipped with professional qualification. Hence the teachers who teach English are actually those who have degree in some other discipline as Islamic studies, social studies and science etc. Though this is not to say that merely gaining qualification in English prepares one to teach English yet holding a degree in English is an important indication of retaining relevant subject knowledge as it can enhance professional confidence and motivational level of the teacher.

In a nut shell it can be said that the conditions under which English is taught in Pakistani context are unfavorable for learning and teaching both. It has been observed that there is no preset criteria and curricular objectives in the light of which courses should be taught. Moreover, the teachers who teach English as a language are not fortified with effected pedagogical tools. Most of the teachers still rely and implement old and almost obsolete teaching techniques. Inappropriate textbooks have been under practice for teaching English as second language, there is no use of extra material or audio-visual aids, examination system is erroneous, as it falls short of attainment, education system as a whole lacks feedback mechanism and needs to be observed on regular basis.

\section{RECOMMENDATIONS}

Based on the discussion and conclusion above, the researcher would like to recommend the following to bring some improvement in the teaching English as second language in education system at early stage so that students do not face problems and English language does not prove to be a barrier in their achievement at graduate level. Whereas if they are taught properly, they would not feel the necessity to go for separate English language classes when they enter their graduate level.

First of all, researcher believes that more attention should be given to language teaching at primary level. English language should be taught as language not merely as subject at schools so that students' need is fulfilled at early stage. For this very aim not only training programs, workshops should be held but increasing the number of periods and time too would be helpful. This will produce students with good command of English from beginning till they reach to graduate level.

Attention should be given on students' various issues related to difficulties they 
face in learning English in early classes. As kreshan's theory elaborates anxiety among students have negative impact on learning second language so instructor should try to minimize the anxiety level of students and give them more time advising them to talk about their language complications they come across, so that the hurdles could be removed.

Another good way to improve students' communication skills is to provide them student- centered classes rather than only teacher centered classes. Student to student interaction should be encouraged in order to empower them in language as per their need. Kreshan $(1981,1982)$ suggests that if natural environment having interactive opportunities are being provided it can help in improvement of a language.

English is used as second or foreign language in Pakistan. It is not native of the inhabitants of the country so it needs extra motivation and hard work to be done upon. Motivation is an influential factor that can foster learning. Students should be encouraged and motivated by the people around them be it family members or at school instructors to work hard in their early study or school time so that they have good knowledge of English language which is needed for higher/ graduation level. When students are not motivating to learn something new in the class, they feel boredom, and disturb the class environment too which can have negative impact on learning.

\section{REFERENCES}

Coleman, H. (2010). Teaching and Learning in Pakistan. British Council.

Government of Pakistan, Ministry of Education. (2009). National Education Policy

Government of Pakistan, Ministry of Education. (2006). National Curriculum for English Language Grades I-XII

Crystal. D (1997) English as a Global Language. Cambridge: Cambridge University Press.

Dornyei, Z. (2007). Research methods in applied linguistics.

Farooq, M. S., Chaudhry, A. H., Shafiq, M., \& Berhanu, G. (2011). Factors affecting students' quality of academic performance: a case of secondary school level. Journal of quality and technology management, 7(2), 1-14.

Ghenghesh.P, Hamed.M \& Abdelfattah.Y. (2011). A Study of Perceptions of English Needs of Business Students and the Faculty of Business at the British University in Egypt. Arab World English Journal. 2 (1). 
Jamil, S., Majoka, M. I., \& Khan, M. S. (2014). A study of vocabulary building in English language curriculum at primary level in Pakistan. Journal of Elementary Education, 24(1), 31-45.

Kachru, B. B. (1986). The alchemy of English: The spread, functions, and models of non-native Englishes. University of Illinois Press.

Krashen, S. D. (1982). Child-Adult Differences in Second Language Acquisition. Series on Issues in Second Language Research. Newbury House Publishers, Inc., Rowley, MA 01969.

Krashen, S. D., \& Terrell, T. D. (1983). The natural approach: Language acquisition in the classroom.

Leather, J. \& James, A. (1996). Second language speech. In W. Ritchie \& T. K. Bhatia, Handbook of Second language acquisition. San Diego: Academic Press.

Mahboob, A. (2009). English as an Islamic language: A case study of Pakistani English. World Englishes, 28(2), 175-189.

Mahdi, D. A. (2015). Strategies and Techniques for Fostering Oral Communication Confidence in EFL Students. Arab World English Journal, 6(2).

Manan, S. A., David, M. K., \& Dumanig, F. P. (2014). Language management: A snapshot of governmentality within the private schools in Quetta, Pakistan. Language Policy, 1-24.

Manzoor, F., Ahmed, M., \& Gill, B. R. (2014). Use of motivational expression as positive reinforcement in learning English at primery level in rural areas of Pakistan. British Journal of English Linguistics, 2(3), 30-42.

McKay, S. L. (2003). Toward an appropriate EIL pedagogy: Re-examining common ELT assumptions. International journal of applied linguistics, 13(1), 1-22

Murtonen, M. (2005). Learning of quantitative research methods. Retrieved November, 20, 2012.

Mustapha, W. Z. W., Ismail, N., Singh, D. S. R., \& Elias, S. (2010). ESL students communication apprehension and their choice of communicative activities. ASEAN Journal of Teaching and Learning in Higher Education, 2(1), 22-29.

Norton, B. (2010). Identity, literacy, and English-language teaching. TESL Canada Journal, 28(1), 1.

Nun Nawaz, S., Umer, A., Tabasum, M., Zaman, M., Batool, A., \& Aslam, S. Difficulties facing by students of L1 in adopting L2an, D. (1992). Research methods in language learning: Cambridge University Press.

Pennycook, A. (2014). The cultural politics of English as an international language: Routledge.

Rehman, A., Bilal, H. A., Sheikh,A., Bibi. N., and Nawaz. A. (2014). The Role of Motivation in Learning English Language for Pakistani Learners. International Journal of Humanities and Social Science, 4 (1); January 2014

Rahman, T. (1995). The Pashto language and identity-formation in Pakistan. Contemporary South Asia, 4(2), 151-170.) 
Rahman, T. (2006). Language policy, multilingualism and language vitality in Pakistan. Trends

in linguistics studies and monographs 175: 73 https://en.wikipedia.org/wiki/Pashto\#Pakistan)

Richards. J. C., and Schmidt, R. (2010). Longman dictionary of Language Teaching and Applied Linguistics (4th ed.). Pearson education limited, London, UK

Roach, P. (2000). English Phonetics and Phonology. London: Cambridge University Press.

Sabri, U., \& Qin, T. Y. (2014). Communication apprehension among Nilai college students. Advances in Language and Literary Studies, 5(5), 46-49.

Sadiq, N. (2015). English as a Social Symbol of Prestige \& Its Impact on Urdu Language Speakers. European Journal of Academic Essays, 2(8), 41-45.

Saeed, A., Iqbal, T., \& Azam, R. Perceptions of Teachers regarding English-medium Instructions.

Sekhar, G. R. (2012). The impact of english language on contemporary world: A global perspective. Asian Journal of Multidimensional Research, 1(4), 146, 155.

Shah, T. (2008). An exploration of attitudes towards the English curriculum in educational establishments in urban and rural Pakistan. University of Glasgow.

Shamim, F. (2008). Trends, issues and challenges in English language education in Pakistan. Asia Pacific Journal of Education, 28(3), 235-249.

Singh, M. (2014). Undergraduates' perception of the English language proficiency courses at tertiary level. International Journal of Humanities and Social Science, 4(12), 185-190.

Speaker, N. N. E. Amuyong elementary school intermediate pupil's attitude towards the English Language 2011-2012.

Starks, D., \& Paltridge, B. (1996). A note on using sociolingustic methods to study nonnative attitudes towards English. World Englishes, 15(2), 217-224.

Tariq, A. R., Bilal, H. A., Sandhu, M. A., Iqbal, A., \& Hayat, U. (2013). Difficulties in learning English as a second language in rural areas of Pakistan. Academic Research International, 4(6), 103.

Tegey, H. \& Robson, B. (1996). A Reference Grammar of Pashto. Washington, DC: Office of International Education.

Walqui, A. (2000). Access and Engagement: Program Design and Instructional Approaches for Immigrant Students in Secondary School. Topics in Immigrant Education 4. Language in Education: Theory and Practice 94: ERIC.

Warsi, J. (2004). Conditions under which English is taught in Pakistan: An applied linguistic perspective. Sarid Journal, 1(1), 1-9.

Yahya, M. (2012). A study of the language difficulties of the English Language Center (ELC) students at the Arab American University of Jenin. Asian Journal of Management Sciences and Education, 1(2), 119-1130. 